\title{
BIOTECHNOLOGY OF WASTE WATER TREATMENT WITH SPECIAL REFERENCE TO REMOVAL OF TOXIC METALS. FROM INDUSTRIAL WASTE WATERS
}

\author{
S. WIDANAPATHIRANA \\ Dept. of Microbiology, University of Kelaniya
}

The maintenance of environmental quality has been a continuing problem since the dawn of civilization. Man through his industrial, agricultural and domestic activities has brought about physical, chemical and biological modifications to his environment many of which have had a deleterious effect. Biotechnology will exert an impact on the control and improvement of environmental quality in a variety of ways.

Man's waste has been dealt with for several thousands of years by natural biological processes, controlled through contained biological systems. At present, in many countries, domestic and municipal waste treatment plants as well as some industrial waste treatment plants carry out a series of treatment processes which include the following basic operations:

1. Primary treatment which removes solids which are either disposed or processed by sludge digestion.

2. Secondary treatment (biological) which degrades dissolved organic compounds. This is effected by natural aerobic microorganisms. Aerobic effluent treatment is the largest controlled use of microorganisms in biotechnological industries. Three major methods are used viz. trickling filter system, activated sludge, oxidation ponds. This process reduces the biological oxygen demand (BOD) of the waste.

3. Tertiary process (optional) involves the chemical precipitation and removal of phosphorous and nitrogen.

4. Final treatment to disinfect and dispose the liquid effluent.

5. Solid processing or sludge treatment - In this process solid arising from primary and secondary stages is digested using anaerobic processes. This reduces the solid volume, odour, number of pathogens and in addition generates valuable organic fuel, methane.

The processing of industrial waste arising from biologically based industries, such as the food, drink and fermentation industries have been treated usually by biological oxidation methods mentioned above. However waste arising from chemical industries have created new ecological problems involving environmental pollution. The diverse activities of the chemical industry generate a plethora of waste compounds, many of which are toxic and re-calcitrant, and therefore persistent in the environment. Industries such as mining electroplating tanneries, chemical plants, and paper mills 
discharge effluent containing chromium, arsenic, cyanide, mercury, gold in remarkable concentrations. In countries which use nuclear energy, effluent contains small amounts of uranium. Therefore many of these industrial effluents require chemical or physical pretreatment before conventional biological effluent treatment can be used.

In many countries the toxic metals in the effluents are removed by chemical precipitation or ion exchange methods. The technology involved is not only expensive and inefficient but also adds more pollutants to the system. Many countries such as USA, Russia, have now developed methods using microorganisms or microbial procesess to remove metals from waste water. Such biological methods form the basis of some novel methods of industrial waste treatment. Some of these methods are described below.

\section{Metal Precipitation in the Presence of Plant and Plant Decomposition Products}

In these methods heterotrophic microorganisms are encouraged to grow in waste water by the addition of cheap organic substances such as molasses, plant decomposition products. This leads to the reduction/oxidation of metal ions and their precipitation in the form of sulfides.

Oxidation pond constructed on the same principle of removal of metals by heterotrophic bacteria, plant and plant products is shown in Figure 1. This oxidation pond, which is connected to waste water reservoir, operates on a continuous flow system consisting of several compartments which contain water plants and sugar beet molasses to enhance microbial flora. Plants saturate water with oxygen, enrich organic materials in the pond, absorbs some metals and also increase microbial activities. Water and silt microorganisms in a biological pond promote removal of metal ions from waste waters flowing into the biological pond. This was observed to vary due to uneven rate of metal removal in different zones of the pond. In the initial vegetation free part of the pond metal concentration in the effluent does not change significantly. Purification is markedly enhanced after the metal ions enter the vegetated area, where there is a greater number of microorganisms that mineralizes the organic substances. Metal bound to organic substances as well as in the form of sulfides precipitate to the bottom.

Table 1: Purification of waste water from a tailings pond in a continuous-flow vessel

\begin{tabular}{|c|c|c|c|c|c|}
\hline Chemical composition & Initial content, & \multicolumn{3}{|c|}{ Period of treatment, days } & Degree of \\
of wastewater & $\mathrm{mg} /$ & 10 & 20 & 30 & purification \% \\
\cline { 3 - 5 } $\mathrm{pH}$ & 10.2 & 9.0 & 8.4 & 8.2 & \\
\hline Cyanides & 14 & 4.8 & 3.5 & 0.5 & 96 \\
Copper & 5.8 & 1.4 & 0.7 & 0.5 & 91 \\
Zinc & 1.3 & 1.0 & 0.5 & 0 & 100 \\
Lead & 0.25 & 0 & 0 & 0 & 100 \\
\hline
\end{tabular}



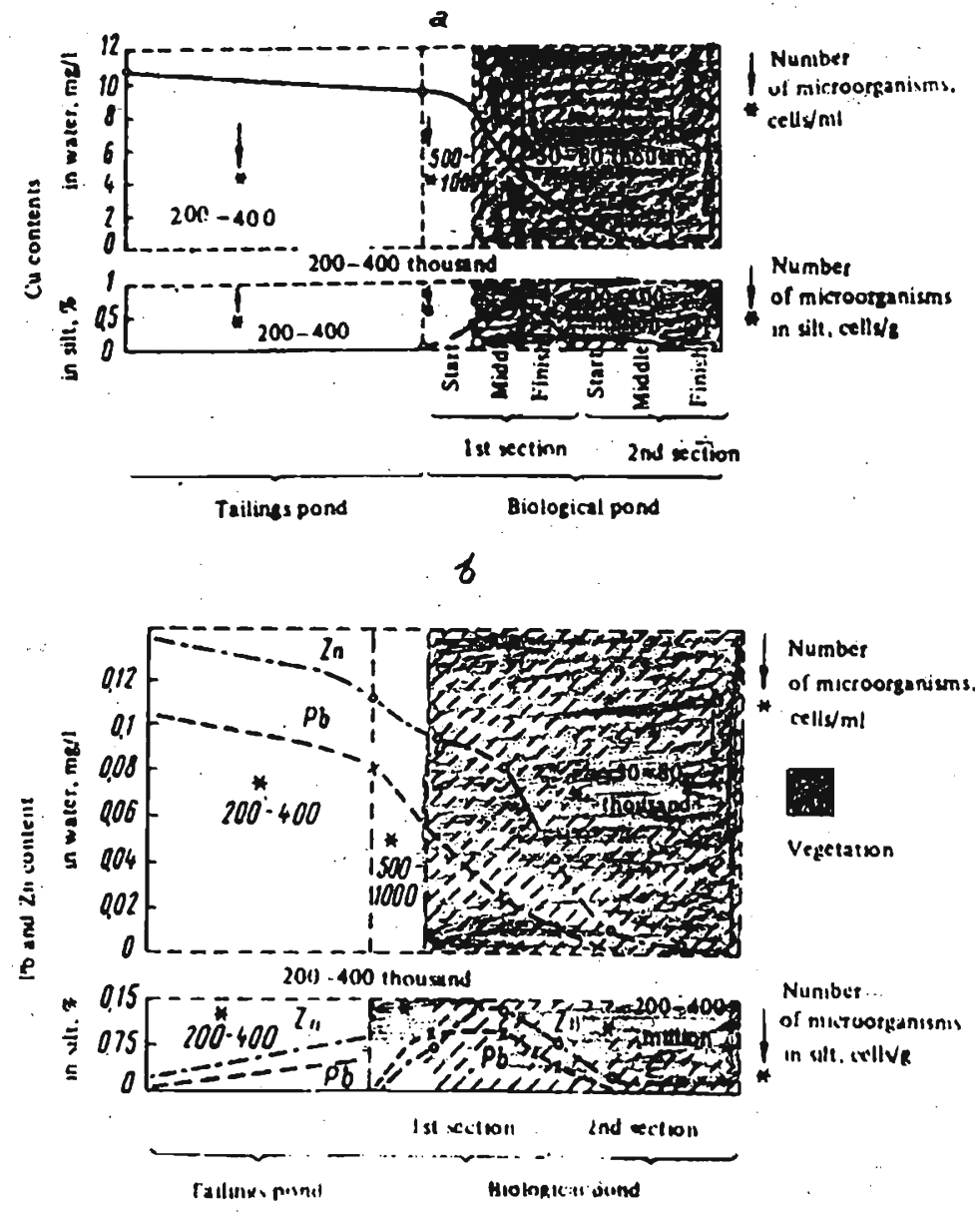

Figure 1: The dynamics of copper (a), lead and zinc (b), content in water and silt of purincation units in non-ferrous metallurgical plants

\section{Oxidation / Reduction of Metals in Waste Water}

Microbial processes have been used to remove arsenic from industrial effluents. Arsenic and its combinations are very toxic and cause grave effects. Trivalent arsenic (As ${ }^{+3}$ Arsenite) is soluble and can be found in the effluents of processing plants of $\mathrm{Cu}, \mathrm{Ni}, \mathrm{Zn}, \mathrm{Pb}, \mathrm{Au}$ and sulphuric acid plants. Arsenites $\left(\mathrm{As}^{+3}\right)$ are more soluble and toxic than arsenates. For complete removal arsenic must be converted into pentavalent form $\left(\mathrm{As}^{+5}\right)$, i.e. it must be oxidized. Chemical methods of oxidation of $\mathrm{As}^{+3}$ to $\mathrm{As}^{+5}$, are not satisfactory. Microbial processes based on pure cultures or mixed cultures of Pseudomonas putida, Pseudomonas arsenitoxidans, Alcaligenes eutrophus have been used to detoxify such industrial waters. They oxidize $\mathrm{As}^{+3}$ to $\mathrm{As}^{+5}$ in the presence of organic substances. Oxidation of $\mathrm{As}^{+3}$ is carried out by 
molecular oxygen produced during decomposition of $\mathrm{H}_{2} \mathrm{O}_{2}$ by catalases and peroxidases produced by microorganisms.

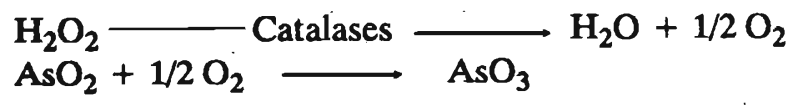

Pseudomonas arsenitoxidans is an autotrophic bacteria isolated from industrial waste water from gold industry. It can oxidize $\mathrm{As}^{+3} \longrightarrow \mathrm{As}^{+5}$ utilizing autotrophic $\mathrm{CO}_{2}$.

Figure 2 shows a plan of an industrial set up used for detoxifying waste water containing arsenite. In this bacterial cells are immobilized in a column which contains bentonite and montmorillonite clay, wood chips and polystyrene beads. Beet pulp is added as nutrients for the microorganisms. Sewage containing As ${ }^{+3}$ flows into the column at a given speed. After oxidation phosphoric acid and calcium hydroxide are added to form $\mathrm{Ca}$-As -P complex which is insoluble and can be separated (Figure 3).

Waste water containing $\mathrm{Cr}^{+6}$ compounds are produced in galvanizing industry, electroplating industry, tanneries, radio electronic industry and the fur manufacturing industry. Hexavalent chromium compounds-are water soluble and highly toxic. Even in small concentrations $\mathrm{Cr}^{+6}$ affects planktons, photosynthetic algae, cyanobacteria and many bacteria. Chromium $\left(\mathrm{Cr}^{+6}\right)$ in water reservoirs can suppress the cycling of nutrients in aquatic systems.

In industries $\mathrm{Cr}^{+6}$ is converted into $\mathrm{Cr}^{+3}$ which is less toxic and insoluble using acid and subsequent precipitation by alkali to form $\mathrm{Cr}(\mathrm{OH})_{3}$. Many countries now employ microbiological processes to reduce $\mathrm{Cr}^{+6}$ to $\mathrm{Cr}^{+3}$. These microorganisms include Pseudomonas dechromatica and Pseudomonas chromatophila. They are able to use chromates and dichromates as acceptors of electrons when grown anaerobically on organic media. As a result $\mathrm{Cr}^{+6}$ is reduced to $\mathrm{Cr}^{+3}$ which is precipitated as $\mathrm{Cr}(\mathrm{OH})_{3}$.

Cyanides are found in industries such as electroplating, coke, gas plants, and gold extraction. Biological methods of sewage purification from cyanide are now in practice, several bacteria have been isolated and are now being used in some industries. These includes Bacillus sp, Bacillus brevis, Pseudomonas fluorescenes. Homestead Gold Mining Corporation in USA developed a method in 1985 which uses a strain of Pseudomonas paucimobilis to decompose cyanides and thiocyanates to $\mathrm{CO}_{2}$ and ammonia with a simultaneous adsorption of $\mathrm{Ni}, \mathrm{Cu}, \mathrm{Pb}$ and other heavy metals in waste water in a system consisting of a rotatory biological contactor (RBC) with immobilizid bacteria. 


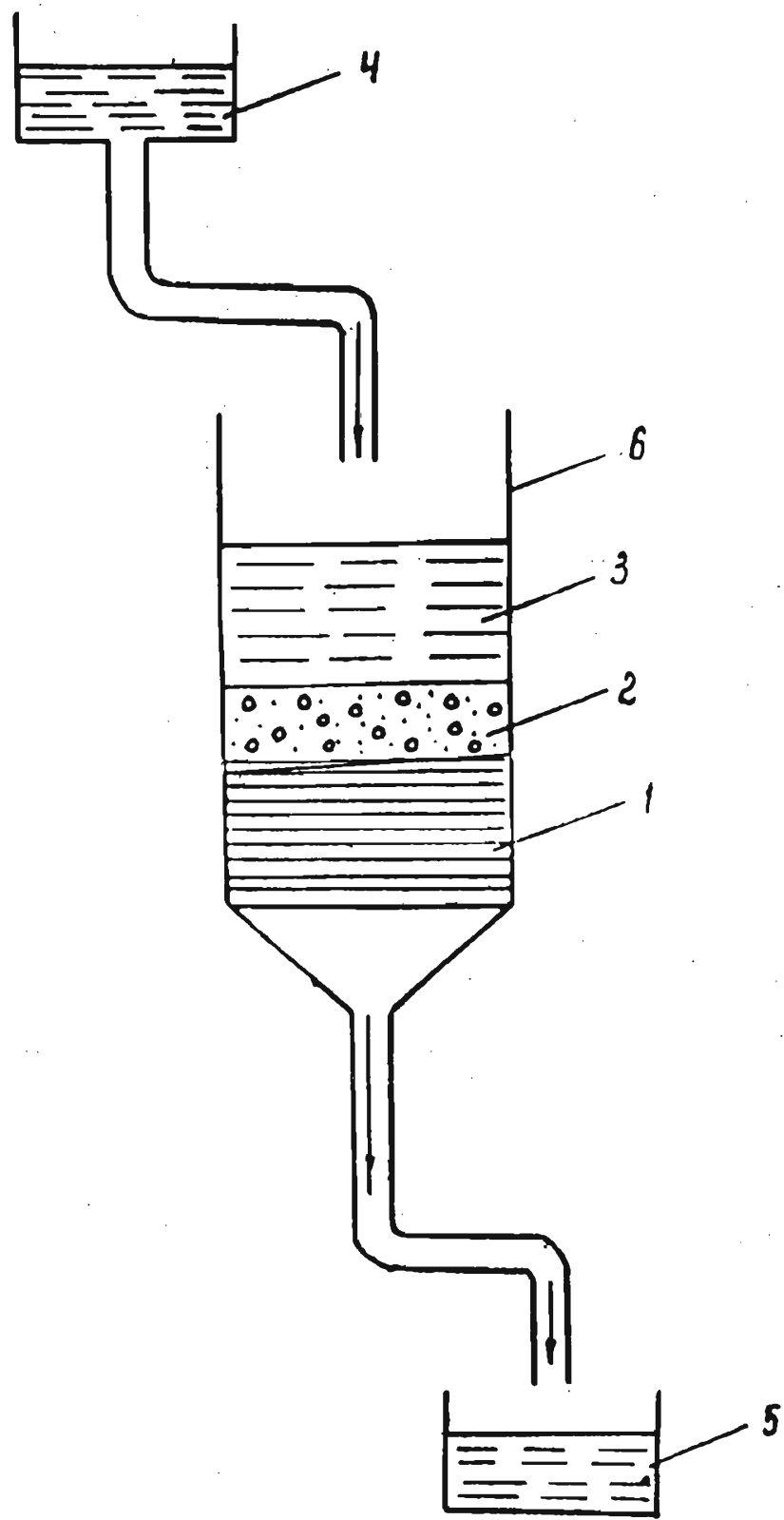

Figure 2: Scheme of installation for bacterial ocidation of arsenite:

1 - poloplast;

2 - adsorbent with bacteria;

3 - water layer with $\mathrm{As}^{3+}$;

4- water to be purified;

5 - water flowing out of the column with $\mathrm{As}^{5+}$

6 - column with immobilized bacteria. 


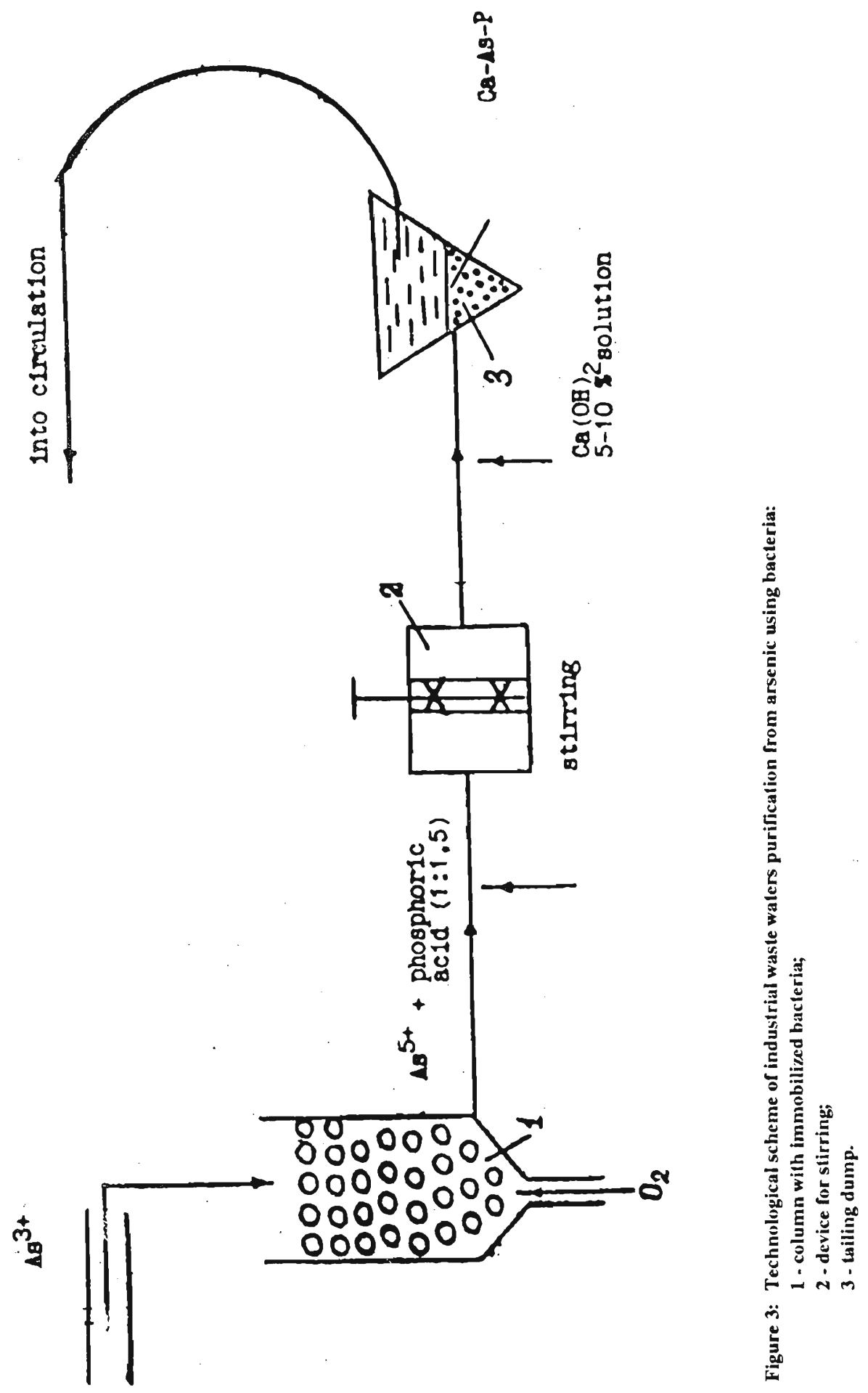




\section{Biosorption of Metals}

Biosorption is based on the interaction of metals with superficial cellular structures of microorganisms with microbial metabolites and extracellular polysaccharides. This process exploits the ability of microorganisms to selectively extract metal ions from dilute solution. This is called biosorption, many living and non living cells are active in metal accumulation at high concentrations. Their ability to biosorb metals depend on the presence of biopolymers in the cell wall and capsule, because in aqueous solution they have a definite charge as a result of functional group ionization. These properties of microorganisms are used to remove or recover metals in industrial waste water. The present technology involves immobilization of microorganisms using inert carriers in a column or vessel. When waste water solution passes through they adsorb bind metals from the solution. Accumulated metals may be recovered by desorption to obtain valuable metals (gold, uranium, etc.) from the biomass by various eluting solvents. After desorption biomass can be re-utilized. (Table 2)

Table 2 : Desorption of metals from the biomass of micro-organisms

\begin{tabular}{llll}
\hline Biomass & Desorbent & Metal & Recovery \% \\
\hline $\begin{array}{l}\text { Arthrobacter } \\
\text { viscosus }\end{array}$ & $0.1 \mathrm{~N} \mathrm{HNO}_{3}$ & $\mathrm{Cd}$ & $65-80$
\end{tabular}

2. Zoolgloea rasigara

$\mathrm{HCl}, \mathrm{pH} 2-4$

$\mathrm{Cu}, \mathrm{Cd}$

$90-100$

3. Zoolgloea rasigera

0.25 N NTA.

Cd

77-95

pH 6.0

4. Chlorella regularis

0.01 M EDTA

Cd

pH 4.9

$88-92$

5. Chlorella vulgaris

pH 1.5

$\mathrm{Cu}, \mathrm{Fe}$

100

Thiourea

Au 100

6. Chlorella

0.1 M Thiourea

Au

99.4

pyrenoidosa

7. Cyanidius caldarus

$---\cdot-1$

8. Chlorella

pyrenoidosa

$\mathrm{H}_{2} \mathrm{SO}_{4}$

$\mathrm{Cu}$

Mercaptoethanol $\mathrm{Au}, \mathrm{Hg}$

9. Rhizopus arrbizus

$\mathrm{NaOH}, \mathrm{pH} 9-10$

Mo

90-95 
Table 1 Contd.

\begin{tabular}{llll}
\hline Biomass & Desorbent & Metal & Recov \\
\hline 10. Candida scottii & $-\cdots-\cdots--$ & & \\
11. Micrococcus luteus & EDTA & $\mathrm{Sr}$ & \\
& Citrate & & 69.2 \\
& $\mathrm{HCl}$ & & 52.0 \\
& & & 55.0
\end{tabular}

12. Ulva sp.

\begin{tabular}{lll}
$0.1 \mathrm{NEDTA}$ & $\mathrm{Zn}$ & $75-85$ \\
\hdashline $\mathrm{M} \mathrm{Na}_{2} \mathrm{CO}_{3}$ & $\mathrm{As}$ & $20-30$ \\
$\mathrm{Zn}$ & $>75$
\end{tabular}

13. S. cerevisiae

$\begin{array}{lll}\mathrm{H}_{2} \mathrm{SO}_{4}, \mathrm{HNO}_{3} & \mathrm{Cu}, \mathrm{Zn}, \mathrm{Mn} & 100 \\ 0.1 \mathrm{~N} \mathrm{EDTA} & \mathrm{Cu}, \mathrm{Mn} & 50 \\ 1 \mathrm{M} \mathrm{Na}_{2} \mathrm{CO}_{3} & \mathrm{Zn} & >75 \\ \mathrm{H}_{2} \mathrm{SO}_{4}, \mathrm{HNO}_{3} & \mathrm{Cu}, \mathrm{Zn}, \mathrm{Mn} & 100 \\ 0.1 \mathrm{~N} \mathrm{HCl} & \mathrm{Zn} & 53-97\end{array}$

14. Aspergillus niger

15. Claviceps paspali

16. Penicillium chrysogenum

17. Ascophillus cocosus

$0.1 \mathrm{M} \mathrm{SO}_{4}-2$

Co

95

pH 5.2

18. Ascophillus cocosus

$0.1 \mathrm{M} \mathrm{CaCl}_{2}$

Co

$$
\mathrm{pH} 2.0
$$

pH 2.5

96

pH 5.7

91

EDTA

Co

$\mathrm{pH} 2.5$ 
The objective of this presentation is to publicize the wide scope of biotechnology in the hope that this may stimulate some basic research on this aspect, in Sri Lanka. As seen above this biological processing of industrial waste has a great potential in the future. This technology draws a number of scientific disciplines, including biochemistry, chemistry, genetics, microbiology and chemical engineering. Therefore it must be emphasized even at this late stage, that any development of biotechnology in this country, must precede or accompany a substantial committment by policy makers, administrators, educationists, to upgrade the nature of science education in Sri Lanka. 